\title{
The Potential Contribution of Ethiopian Diaspora in Development: The Presenting Absent Partners
}

\author{
Tariku Raga Lencho \\ Department of Political Science and International Relations, Dire Dawa University, Dire Dawa, Ethiopia
}

Email address:

tarikuraga@yahoo.com

\section{To cite this article:}

Tariku Raga Lencho. The Potential Contribution of Ethiopian Diaspora in Development: The Presenting Absent Partners. Humanities and Social Sciences. Vol. 5, No. 1, 2017, pp. 14-25. doi: 10.11648/j.hss.20170501.14

Received: December 22, 2016; Accepted: January 3, 2017; Published: February 21, 2017

\begin{abstract}
This day, it seems that there is a general consensus among scholars and policy makers that Diaspora could play paramount roles in enhancing development processes to alleviate poverty in developing countries like Ethiopia. This study aimed to elicit the potential roles of Ethiopian diaspora in promoting the country's development. Eventhough numerous scholarly works exist on Diaspora related issue, there were no literatures concerning the potential roles of Ethiopian diaspora in accelerating the country's development efforts. This paper attempts to highlight: (i) the potential roles of Ethiopian Diaspora in the promotion of the country's development (ii) important initiatives taken by the government to draw the Diaspora to participate in enhancing the development endeavors of the nation and (iii) the factors hindering the diaspora not to participate in the country's development. The study uses different government proclamations/official documents/, other literatures and personal reflections to examine the potential roles of Ethiopian diaspora in enhancing country's development. Overall, despite the fact that the government has made some initiatives and/or efforts to attract the diaspora to the country, there are factors which obstruct their return to the country such as lack of political and economic environments like execution capacity, inefficient government bureaucracy, weak institutions and corruption, lack of good governance at the grass root level and strong political commitment to democratize the state on behalf of the government. More than any other issue, building a democratic political culture at home is an important prerequisite for the return of Diaspora. In this regard, Ethiopia needs to create an enabling environment and establish strategic collaborations and partnerships with all its Diasporas.
\end{abstract}

Keywords: Development, Diaspora, Ethiopia, Poverty Alleviation

\section{Introduction}

\subsection{Background of the Study}

This day, most countries in the world have recognized the important role that their respective Diasporas could play in economic growth and development. In Africa and Europe, for example, the roles of migrants and Diasporas in development processes have been increasingly highlighted. This include transfer to their country of origin- especially through remittances-financial support for development projects, the formation of Diasporas led development organizations and direct personal involvement of diasporas members in development initiatives. As a result, this has led to a search for policy initiatives to maximize their contribution.

The emergence of such development oriented Diasporas is a recent phenomenon. Previously such positive relationship between Diasporas and development were rarely recognized (Bakewell, 2009:1). Until late 1990s, Africans emigrants were seen as embodying the brain drain and carrying away the skills of the continent. Their remittances were received by their relatives, but many argued that this flow of money was used for 'conspicuous consumption'- rather than investmentand increased inequality between households (ibid). There were also concerns about the political influence of Diasporas, which were sometimes seen as contributing to conflict and corruption (Lyons, 2009:2).

The emigration from Ethiopia is a recent phenomenon that began in the 1970s with the outbreak of Ethiopian revolution of 1974, which led to two decades of conflict and large refugee out flows from the country. In the 1980s, refugee crisis in the horn of Africa was the largest in the world with 
over one million Ethiopian refugees residing in the neighbouring countries of Sudan and Kenya (Kuschminder and Siegel, 2010:2). The majority of these refugees were got asylum in the United States and Europe though Some of them returned to Ethiopia in the 1990s. Currently, emigration from Ethiopia has continued with both low and high skilled migrants because of political and economic reasons (Tewabech, 2011). Opposition party members, bloggers and journalists have migrated to different developed countries because of unfavorable political environment in the country and young Ethiopian women have also migrating to Arab countries in search of better employment opportunities.

Though much of the Ethiopian Diaspora is concentrated in the European countries and USA, it is not uncommon to find Ethiopians or Ethiopian origin of other country's citizens in almost every countries of the world. Ethiopian Diaspora left the country for varieties of reasons including political, social and economic and others.

Several developing countries, including Ethiopia, are making coordinated effort to attract their Diasporas. However, there could be multi-faceted problems affecting their return back home like lack of conducive political and economic environment such as execution capacity, inefficient government bureaucracies, weak institutions and chocking corruption. These are probable constraints, which deter the Diaspora from participating in their countries development effort.

Even though the government of Ethiopia developed policy regarding investment, housing and citizenship, most of the Diaspora's political orientation and inclination appears not go along with these policies and laws. Thus, their contribution to the country's economic development might be unsatisfactory.

\subsection{Statement of the Problem}

The Ethiopian government has officially acknowledged the important roles of the Diaspora to the countries development over the past decades. However, the progress observed in engaging the Diaspora in the development process seems not good enough. This could be largely attributed to the absence of comprehensive national Diaspora policy and unfavorable political and economic environment prevailing in the country.

Thus, the objective of this study is to identify the potential contributions of Ethiopian Diaspora in the country's development and the factors hindering them from participating in the development process. No study has conducted regarding the potential contributions of Ethiopian Diaspora in development of the country in a broader context. Despite the fact that Ethiopian Diaspora has been engaging in the politics and development of the country since the last two decades, little or no attention has been given to the area of development. Even if the issue is sensitive, it lacks the attention of scholars and policy makers. But, this does not mean that there is no any literature concerning Diaspora and development. It is important to mention few literatures on the Ethiopian Diaspora and development. For instance, Tewabech Bishaw (2011), Kuschminder (2010), Kuschminder and Siegel (2010), Chacko and Price (2009) and Lyons (2009) tried to discuss the role of Ethiopian Diaspora from different aspects.

In her study entitled "the Role of the Diaspora in Knowledge Exchange Network for National Growth and Social Change in Ethiopia" Tewabech Bishaw (2011) explained Diaspora's role in knowledge exchange. Her study was limited only to the role of Diaspora in knowledge exchange and didn't address the overall potential contribution of the Diaspora in development of the country.

Under the title "Diaspora engagement policies in Ethiopia" Kuschminder (2010) on his part briefly discussed the attempts made by the government to formulate the Diaspora policy. The study mentions nothing about the potential contribution of the Diaspora in the development of Ethiopia.

Kuschminder and Siegel (2010) in their study entitled "Understanding Ethiopian Diaspora engagement policy" also stated about the institutional and policy arrangements developed in Ethiopia and their effects on the Diaspora. Nothing stated about Ethiopian Diaspora in relation to development. This study largely attempts to fill this gap.

Furthermore, Chacko and Price (2009) in their study entitled "the Role of the diaspora in Development: the case of Ethiopian and Bolivian immigrants in the United States" briefly discussed the roles of the Ethiopian and Bolivian Diaspora in the USA. In their comparative study of the two countries, they did not focus on efforts made by government to engage them in the development process nor the challenges the diaspora faced in participating in the poverty reduction which this study takes into consideration. Their comparison was only in terms of remittance contribution only.

Terrence Lyons (2009), in his study entitled "The Ethiopian Diaspora and Homeland Conflict" discussed the role of Ethiopian Diaspora in the May 2005 elections of Ethiopia. He argued that the influence of Ethiopian Diaspora was explicitly visible in the decision of the opposition parties (mainly CUD) to participate in the elections and whether to stay or leave the parliament after the election. His study was limited to explaining the role of the Diaspora in that particular election and their participation in home land conflict in the aftermath of the election and he did not mention the overall potential contribution of the Diaspora in the country's development. Generally, this study fills the existing gap in literature in the area of Diaspora and development which lacks strong consideration in contemporary Ethiopian Political Economy by the country's policy makers and politicians.

\subsection{Objectives of the Study}

The general objective of the study is to identify the potential roles of Ethiopian Diaspora in promoting the development of the country. The Study has the following specific objectives:

- To explore the potential contributions of Ethiopian diaspora in the promotion of the country' development.

- To identify the initiatives taken by the government to attract the diaspora to participate in the development endeavors of the country. 
- To find out the factors hindering the Diaspora's participation in the country's development.

\subsection{Methodology and Sources of Data}

Methodology in a research is a way to systematically solve the research problem and it may be understood as a science of studying how research is done scientifically (Kothari, 2004). This study is based on extensive library work. In the course of doing this research, the researcher has used secondary sources of data such as books, journal articles, magazines, relevant government documents (proclamations), as well as internet sources. The study also used personal reflections to examine the challenges facing Ethiopian Diaspora in promoting country's development. However, it will be challenging to obtain sufficient data that will specifically be a high-quality input for analyzing the issue due to the sensitive nature of the topic and a highly politicized part in the current politics of the country. Because of this, the study becomes declarative in nature. Due to the nature of the topic and the theoretical tool employed to analyze the issue under discussion, methodologically the relevant information from secondary sources through the above methods are described and analyzed qualitatively.

\subsection{Significance of the Study}

The researcher believes that the participation of the Diaspora in the development process enables the country to reduce poverty or promotes the development efforts the country has already started. This study attempts to assess the potential contributions of Ethiopian Diaspora in the development of the country and the challenges they encounter as there is no such research conducted on the issue previously.

Since there were no researches conducted on the potential contribution of Diaspora in the development of the country, this study is intends to pave the way to academic and research communities in order to conduct further research on the issue under discussion. In addition, this study could be an important input for policy makers since it discern out the potential contributions of the diaspora in enhancing the country's development and the factors impeding them not to actively involve.

\subsection{Scope of the Study}

The study mainly focuses on examining the potential contributions of Ethiopian Diaspora in the development of the country, the attempts made by the government to attract them and challenges facing the Diaspora not to actively participate in the development efforts of the country. This study does not delve into the whole analysis of the Diaspora related issue and their role in the country's politics. Issue like their involvement in influencing foreign policy orientation of the country and their contribution in fostering Ethiopian democracy is beyond the scope of this study.

\section{Conceptual Clarifications and Theories on Migrations}

\subsection{The Concept of Diaspora and Transnationalism, and Development}

During the last twenty five years, the term Diaspora and transnationalism have gained increased acceptance in migrations studies, being widely used in shaping the research agendas. Yet, while diaspora is a very old concept, even going to back to historic experiences of Jewish people, transnationalism is relatively new notion appearing on academic literature in the 1990's (Faist, 2010).

The term 'Diaspora' is a long standing term and it has historically been associated with the notion of dispersion of an ethnic population outside their traditional homeland (Proctor, 2003:151). Etymologically, the word 'diaspora' is derived from the two Greek words 'dia' and 'sperien' meaning 'over' and 'sow' or 'scatter' respectively as in the scattering of seed. For them it meant the 'seeding' of Greek colonies in distant lands (ibid). Originally, it was used to refer to the exiles of Jews from Palestine and more recently the term has been adopted and adapted by post colonial scholars and artists to refer to the forced and voluntary migrations set in motion by empire.

Scheffer, defined the concept Diaspora as "a modern Diasporas are ethnic minority groups of migrants origins residing and acting in host countries but maintaining strong sentimental and material links with their countries of origintheir home lands"(2006:4). This definition asserts that Diaspora is a small section of minority migrants living in the receiving state and has strong emotional and material contact with their countries of origin. However, nothing stated through which channel they have arrived (legal or illegal) in their migration.

Another useful definition is provided by the UK House of Commons: "Diasporas are international migrants who are dispersed from their home lands, but remain in some way part of their community of origins" (Sixth Report of Session, 2003-4, Volume1 as cited in Ionescu, 2007:13). This definition captures the following points: individuals are dispersed, possibly across several countries, but they maintain an interest and affiliation to their home country, either, 'real' or 'imagined'. There is no fundamental difference the above two definitions.

The African Union convened an expert meeting for member states in April, 2005 to prepare a definition for the "African Diaspora." The adopted definition is: "The African Diaspora consisted of peoples of African origin living outside the continent, irrespective of their citizenship and nationality and who are willing to contribute to the development of the continent and the building of African Union"(Ionescu, 2007: 15). This broad definition calls attention to a number of significant policy points: a continental instead of national belonging (i.e. a non- national Diaspora definition) and a highly symbolic and political facet. Voluntary belonging to the African Diaspora is intrinsically related to the willingness 
to contribute to the development and support for African Union. This definition, therefore, relates voluntary contributions belonging to a collective entity.

Generally, there is no single accepted definition of the term; "Diaspora", neither is there a legal recognition of the term, which consequently has given rise to many different meanings and interpretations. For the purpose of this study, a broad definition of "Diasporas" is proposed as "a member of ethnic and national communities, who have left, but maintain links with their home lands and willing to contribute to the development of their homeland."

On the other hand, transnationalism is the process whereby people establish and maintain socio-cultural connections across geopolitical borders (IOM, 2008). It centered on exchanges, connections and practices across borders, thus transcending the national space as the primary reference point for activities and identities.

Other scholars like (Smith, 2006 as cited in Levitt and Jaworsky, 2007) defined transnationalism as a practices and relationships that link migrants and their children with the home country, where such practices have significant meaning and are regularly observed. Transnationalism creates a greater degree of connection between individuals, communities, and societies across borders bringing about changes in the social, cultural, economic and political landscapes of societies of origin and destination (IOM, 2010). Sometimes, diaspora and transnationalism can be considered the same and used interchangeably. However, the two concepts reflect different intellectual genealogies having some similarities and differences as clearly mentioned by Thomas Faist (2010). For Faist, both Diaspora and transnationalism deal with homeland ties and the incorporation of persons living 'abroad' into the regions of destination. However, Diaspora approaches usually focus on the relationship between homelands, dispersed people and destination countries (2010:20). He further stated that as the Diaspora relates most often to religious, ethnic and national groups and communities, while transnational approaches connect to all sorts of social formations. Thus, transnationalism is broader than Diaspora. A more clear elaboration of the difference between the two terms was given by Cheran (2003) as 'Diasporas are the result of forced migration whereas transnational communities are the result of voluntary migration'. However, to avoid confusions the longstanding term 'Diaspora' is used in the entire paper.

Like the Diaspora and transnationalism, development is a complex and highly contested concept since it lacks a generally accepted definition due to the multidimensional nature and multidisciplinary approach to it. That is why it has attracted several of definitions from various scholars of different orientations. Here are some of their definitions: According to Rostow (1960: 8), development is the progressive movement from traditional society to the stage of high mass consumption of goods and services. For any human society that wishes to develop, it must go through five stages of development i.e. Traditional Stage, Transitional
Stage, Take-off Stage, Drive to Maturity, Stage of High Mass Consumption (ibid).

Walter Rodney (1972), a prominent African scholar, defined development as "a many-sided process implying for the individual skills and capacity, greater freedom, creativity, self discipline, responsibility and material wellbeing. The process involves the development of tools, skills and the mobilization of required resources for development purpose."

To V. I. Lenin (1968) development is a progressive movement, ascension from lower to higher stages and from simple to complex situations- the simple/lower stage(s) refers to the state of nature in which society finds itself in the process of social evolution.

The World Bank in World Development Report (1991) believes that the concept of development has economic, social and political attributes such as sustainable increase in living standards including consumption, education, health and environmental protection, equality of opportunity and liberties and political freedom.

This study, therefore, uses a more comprehensive definition of development produced by Todaro and Smith (2014:18) which conceived development as "a multidimensional process involving major changes in social structures, popular attitudes, and national institutions, as well as the acceleration of economic growth, the reduction of inequality, and the eradication of poverty." In more practical terms, economic development is a condition by which individuals and society at large enjoy a good quality of life, are free, have opportunities for upward mobility and are able to improve their material circumstances. Three areas that enable these conditions are health, education and material asset accumulation.

\subsection{The Dimensions of Diasporas' Links to Development}

Little theoretical analysis exists regarding the link between Diasporas and development. It can be argued that this link lies at a point where the economic activities of migrants intersect in a way that transforms the material base of migrants, their relatives, and their societies. This transformation takes place along various dimensional spaces. Robinson (2002) speaks of the relationship between Diasporas and development as being three-pronged: a) development in the diaspora, b) development through the diaspora, and c) development by the diaspora. The first refers to the use of networks in the host country, which includes the formation of ethnic businesses, cultural ties, and social mobilization. Development through the diaspora refers to "how diasporic communities utilize their diffused global connections beyond the locality to facilitate economic and social well being" (ibid). The third applies to the ramifications of "the flows of ideas, money, and political support to the migrant's home country" (ibid). Understanding the Diaspora's link to development help us to know how the Diaspora could contribute to the economic development and poverty reduction. 


\subsection{Major Theories on Migration}

After the Second World War, there was a scholarly debate on the issue of international skilled labor migration focusing on the economic implications for home and host countries. In other words, the impact of migration on development in migrant sending communities and countries has been the subject of continuous and sometimes heated debate between opposing (often contradictory) views of the "migration optimists" and "migration pessimists" (de Haas, 2010:3). For the purpose of this study, I want to focus on two opposing perspectives of neo-classical and developmentalist theory, and the world systems theory or the historical-structuralist theory.

\subsubsection{The Neo-Classical and Developmentalist Perspectives: The Optimistic Views}

Neo-classical migration theory considers migration as a form of optimal allocation of production factors to the benefit of both sending and receiving countries. It recognizes the presence of both winners and losers on migrant receiving and sending countries, but argues that migration from low to high wage countries ensures a more efficient use of labor and narrows inter-country wage disparities (de Haas, 2007:11). According to this theory, migration is driven by geographic differences in labor supply and demand and the resulting differentials in wages between labor-rich versus capital-rich countries (Kurekova, 2011:5). The central argument of the neoclassical approach thus concentrates on wages.

The theory emphasizes that the process is not disadvantageous for developing countries, but it could even lower unemployment, raising wages, boost economic growth and house hold welfare in developing countries through great access to resources like remittances and skills of potential returnees. The theory opposes the concept of brain drain and replaces it with "brain overflow" (Gosh and Gosh, 1982: 15). For them, migration is a process of free movement of labour from low to high wage countries and "brain overflow" is the result of over production of brain and inability to be absorbed by the system (de Haas, 2007).

At the micro-level, neo-classical migration theory views migrants as individual, rational actors, who decide to move on the basis of a cost-benefit calculation. Assuming free choice and full access to information, they are expected to go where they can be the most productive, that is, are able to earn the highest wages. This capacity obviously depends on the specific skills a person possesses and the specific structure of labour markets (ibid).

At the macro-level, neo-classical theory explains migration by geographical differences in the supply and demand of labour. The resulting differentials in wages cause workers to move from low-wage, labour-surplus regions to high-wage, labour-scarce regions ((Kurekova, 2011).

The neo-classical theory of migration has been subject to conceptual critique and rich empirical testing. While rigorous, it has been viewed as mechanically reducing migration determinants, ignoring market imperfections, homogenizing migrants and migrant societies and being a historical and static (Kurekova, 2011:7). It generally ignores the effects of home and host countries and leaves out the importance of politics and policies, which are only considered as distortion factors or additional migration costs. Hence, Neo-classical migration theory tends to view migrants as atomistic, utility maximizing individuals, and tends to disregard other migration motives as well as migrants' belonging to social groups such as households, families and communities.

According to dominant views of the 1950s and 1960s in developmentalist theory, return migrants were seen as important agents of change and innovation. Migrants were expected to bring back not only money, but also new ideas, knowledge, and entrepreneurial attitudes (Tewabech, 2011). In this way, migrants were, thus, expected to play positive role in development and contribute to the accelerated spatial diffusion of modernization in developing countries. Also remittances have been given an important role in stimulating economic growth. De Haas (2010) explains this optimism (expectations) as follows:

Such optimistic views reflected 'developmentalist' views which dominated development theory in the first two decades following the Second World War. Rooted in evolutionary views on development, freshly decolonialized countries were expected to quickly follow the same path of modernization, industrialization, and rapid economic growth as many Western countries had gone through. Assuming that capital constraints formed the major problem these countries faced, the developmentalist model postulated that through largescale capital transfer (e.g., through loans, aid and remittances) poor countries would be able to jump on the bandwagon of rapid economic development and industrialization. Internal and international labor migration was seen as integral parts of this process contributing to a more optimal spatial allocation of production factors and, hence, better aggregate outcomes (de Haas, 2010: 5).

\subsubsection{The Historical-Structuralist Theory: The Pessimistic Views}

A radically different interpretation of migration was provided as of the early 1960 s by the historical structural paradigm on development, which has its intellectual roots in Marxist political economy and in world systems theory (Castles and Miller, 2003 as cited in de Haas, 2007: 15). Historical-structuralism has dominated migration research in the 1970s and the 1980s. It considers migration as a natural outgrowth of disruptions and dislocations that are intrinsic to the process of capitalist accumulation. Optimistic views were increasingly challenged under the influence of a paradigm shift in social and development theory towards historicalstructuralist views. Of course, these new views turned the argument of neo-classical and developmentalist approaches completely upside down: instead of decreasing, migration was now seen as increasing spatial (interregional and international) disparities in development levels (Wallerstein, 1979).

The Historical-Structuralist paradigm sees migration as a 
'flight from misery' caused by global capitalist expansion, which is inherently unable to resolve the structural conditions that cause migration (de Haas, 2010:7). On the contrary, migration is seen as aggravating problems of underdevelopment. Hence, migration undermines regional and local economies by depriving communities of their valuable labor force, increasing dependence on core countries (of which remittances are but one manifestation) and stimulating subsequent out-migration.

Historical-structuralists postulate that economic and political power is unequally distributed among developed and underdeveloped countries, that people have unequal access to resources, and that capitalist expansion has the tendency to reinforce these inequalities. Instead of modernizing and gradually progressing towards economic development, underdeveloped countries are trapped by their disadvantaged position within the global geopolitical structure (Kurekova, 2011: 8). They view migration as one of the manifestations of capitalist penetration and the increasingly unequal terms of trade between developed and underdeveloped countries.

Historical structuralists have criticized neo-classical migration theory, stating that individuals have no a free choice since they are fundamentally constrained by structural forces (de Haas, 2010:16). Rather than a free choice, people are forced to move because traditional economic structures have been undermined as a result of their incorporation into the global capitalist system (ibid). Historical structuralists have also been criticized for being too deterministic and rigid in their thinking in viewing individuals as victims or "pawns" that passively adapt to macro-forces, thereby largely ruling out individual agency (ibid).

World systems theory, on the other hand, is one variant of the historical-structuralists theory which emerged in the wake of dependency theory and constructed a more complete and sophisticated historical analysis of the development and expansion of the global capitalist system from the sixteenth century on (Wallerstein, 1979: 27). Building on Wallerstein, the world system theory relates the determinants of migration to structural change in world markets and views migration as a function of globalization (Kurekova, 2011:8), the increased interdependence of economies and the emergence of new forms of production. The expansion of both export manufacturing and agriculture linked strongly to foreign direct investment flows from advanced economies to semideveloped or emerging economies has led to the disruption of traditional work structures and mobilized new groups of population into regional as well as long distance migration (ibid: 8-9). Capital mobility is, hence a crucial factor for the world system theorists. The theory presents capital and labor mobility as interconnected and the two sides of the same coin (ibid).

These two theories of migration wether the "optimists or "pessimists" pay attention to the determinants, causes of migration, the factors which leads individuals to leave their country of origin and the potential impacts of migration on home and host countries. However, the aim of this study is not to investigate those things, rather its aim is to identify the potential contributions of the Ethiopian Diaspora once arrived in host country. How then, Diaspora once they arrived in specific host country staying there for a long period of time accumulating wealth and knowledge, can share their resources and knowledge to their country of origin, Ethiopia. The theories stated above said nothing about conflict and politics driven migrants. Said in other words, most contemporary migration in developing countries is caused by lack of inclusive and participatory political system. A political system which was/is often channeled through one state sanctioned party with opposition groups banned. Such system leaves no room for differences of ideas and opinion and restricts the participation of oppositions to political system may leads to serious human right violations, which would again opens the door for the citizens to migrate or leave their country. Such modus operandi has also been the feature of modern Ethiopian polity. Thus, the majority of the Ethiopian Diasporas are those who were dissatisfied with the political systems of the last two Ethiopian regimes of Derg and EPRDF and preferred to migrate leaving their families and relatives back home. To this end, they left the country fearing persecution and imprisonment (HRW, 2009).

Therefore, Despite the fact that all these theories of migrations have their own weaknesses and strengths, this study takes up the developmentalist (the optimists) outlook and recognizes the positive impact of the Diaspora on home and host countries. The arguments of the developmentalist theory best fit for this study since it considers return migrants (Diasporas) were seen as important agents of change and innovation. It was expected that migrants not only bring back money, but also new ideas, knowledge, and entrepreneurial attitudes. In this way, migrants (Diasporas) were expected to play positive role in development and contribute to the accelerated spatial diffusion of modernization in developing countries. Also remittances have been attributed as important role in stimulating economic growth. Therefore, the emphasis of this study is on the adoption of possible strategy options by which the country benefits from the process of migration by formulating conducive policies so as to effectively mobilize, network and engage the diaspora in the country's development endeavors by "reversing brain drain to brain gain", the approach which is emphasized by victor Oduba (2003:3).

\section{Ethiopian Diaspora: An Over View}

There is no official record of the size of the Ethiopian diasporas, though commonly cited government estimation and figures indicates that between one and two million Ethiopians are living abroad with large populations in the Middle East, North America and Europe (Kuschminder, 2010:7). In the broadest sense of Diaspora, as a dispersion of members of a population from their homeland to a number of host countries, the Ethiopian Diaspora is said to have its origin in the Middle Eastern countries particularly the during Red Sea and India Ocean slave trade. Although the Ethiopian Diaspora in the Indian Ocean is not solely the result of slave 
trade, it was argued that the slave trade was the dominant factor that removed Ethiopians from the country that period in history (Pankhurst and et al 2003:7-18).

The modern Ethiopian Diaspora differs from its ancient and medieval predecessors in virtually every respect when judged according to the criteria set by Butler: circumstance of departure, relation with home land, relations with host country and interrelationship with other Diaspora communities (2001). Thus, the modern Ethiopian Diaspora seems differ markedly from its predecessors on all of the variables suggested by Butler. However, one should not consider the past thirty five years as one homogenous period. If one wants to see the difference in the three consecutive regimes in the past forty years (since Ethiopian Revolution of 1974), each of the variables Butler pointed out must also be viewed historically. The relationship, and even the reasons for dispersal, may change over time. The reasons Ethiopians chose to leave the country have varied over the period from the 1974 Ethiopian Revolution to the present. The Diaspora "consciousness" develops at different rates under different circumstances and patterns of resettlement and integration (Pankhurst and et al 2003:7-10). Their relationships with both Ethiopia and host countries have also evolved over time varying not only from place to place, but also within a single location over the years (Solomon, 2008:08).

Prior to 1974 and during the Ethiopian Revolution which over threw Haile Sillassie I, only a handful of Ethiopians had lived outside Ethiopia. In the wake of the over throw of the emperor, however, many of those studying in the United States were "forced" to remain abroad. They were a highly homogeneous group, drawn from the then monarchical families. Most had attended Ethiopia's elite schools. They were sent abroad with the expectation that they would form the country's next generation of educated leaders in all fields and would shape the country's future (Abye, 2004:141).

As many authors have pointed out, this first generation of supposedly Ethiopian immigrants viewed themselves as "exiles", displaced from their country by circumstances. They expected to return when "normal" conditions were restored. Many didn't accept American citizenship even when it was offered, because they viewed themselves as Ethiopian citizens temporarily forced to live outside their country (Solomon, 2008:141-142). In contrast to the first generation of "exiles," the second wave of migration was far more heterogeneous in its composition. While some represented urban elites who had served in the imperial regime, other was peasants with limited education of few marketable skills (Getachew and Maigenet, 1991).

With the down fall of the Derg regime in 1991, a new wave of Ethiopian refugees was generated. The third wave of Ethiopian Diaspora can be characterized by the post 1991 flows, that continuous to these days. Border conflict between Ethiopia and Eritrea, internal political repression by EPRDF government added to the crisis in the region, have kept many expatriates away from the country while encouraging others to emigrate. In addition, since the mid 1990s more than 50,000 Ethiopians also reached the United States through the Diversity Visa lottery (DV) program (Easter and et al 2010 at www. Ethiopiandiaspora.com accessed 27/08/2016).

The Ethiopian Diasporas can and should be important partners in the country's development process. They are numerous and many of them are highly skilled. There are many possible advantages that could be gained by engaging the Diasporas in the country's development. One of this advantages entails financial supports mainly remittance flows.

Remittance is becoming source of huge capital transfer from the developed to developing countries. Its size is surpassing twice as that of Official Development Assistance and even comparable with the foreign exchange gains of some developing countries from their major export items. Remittance by Diaspora can be tapped better for the development of a country through organized banking systems to ease transfer and by encouraging effective legal transfers (Kassahun and Birhanu et al. 2004:8).

According to the annual report of the National Bank of Ethiopia (NBE), excluding other areas of contribution, official remittance regained amounted over 387 million USD during fiscal year (2009/10) and the figure is increasing yearly (NBE, 2011). This amount excludes the informal remittance transfer which a large portion of Diaspora uses. Most of money flow through unofficial channel to avoid exchange rate restrictions, high taxes and tariffs and bureaucratic requirements. Remittances have a direct impact on poverty reductions since they flow directly to poor households and are used for basic needs such as food, shelter, education and health care and startup capital for new businesses (New land, 2004:2). The common argument that remittances are not used for "productive" investments misses the point that poor households rationally give priority to these basic needs, which represent an investment in human capital as well as basic consumption. Spending on basic needs also has a multiplier effect in the community.

Diaspora is also a source of investment. The Diaspora, if recognized as an asset could invest huge capital in the home country. While these individuals live abroad for a long period of time they have a potential to accumulate capital to be invested returning back to their home country. Attractive government policies that encourage the Diaspora to invest are of course, the pre-requisite. Bureaucratic bottlenecks and long procedures are important factors to be considered to facilitate investment (Shinn, 2002:14). According to the 2009/10 report of Ethiopian Investment Agency (EIA), more than 4.12 billion birr has been invested in various projects by Ethiopians in the Diaspora in the last six years (EIA, 2011). The Ministry of Foreign Affairs (MoFA) also reported that 640 Ethiopians Diasporas have been engaged in Agriculture, construction, health, education and development activities in the last six years (MoFA,2011). This is a good start, but quite small number of Diaspora investing in the country. They have been invested more than 
this if the issue of the Diaspora were handled properly through positive national policy formulation is accompanied like the Indian and Chinese government did. Although the Ethiopian Diaspora is divided because of the traumatic experiences many of its member have under gone and unable to come together to form a united front for constructive development purposes, they are among the most successful of the African Diasporas in Western countries (Lyons, 2009).

Moreover, Diaspora can transfer of knowledge and technology to home country. For transfer of knowledge and technology, government initiative to form linkages with groups of Diaspora working in academic and research institutes and scientific fields are crucial. Individuals will most likely agree to use their sabbatical leaves and spare times to help their country without necessary returning home or in short term visits. This is a double blessing to the country since they best know the country's situation and their relative cooperation to work in low pays than foreign expertise. But, little or no participation of Ethiopian Diaspora in technology and knowledge transfer.

Furthermore, Promotion, public relation and Lobby work is another potential contribution from the Diaspora. Citizens in overseas can act as 'ambassadors' by forming constituency of community in different occasions. For instance, they can promote culture, tourist sites, cooperate investment schemes, promotes the positive images of their country, and act on public diplomacy as lobby groups to influence other government (institutions) for national advantage(Seyoum, 2000). The opposite is true of Ethiopian Diaspora. For example, after 2005 election, they become engaged in new ways in homeland politics through fundraising, lobbying and engaging in political debates. Particularly the Diaspora moved away from support for electoral politics towards lobbying for International Financial Institutions of IMF and World Bank in order to stop financial aid and loans to Ethiopia which might affect the countries development effort. Thus, they can change the image of the country negatively by exposing/magnifying the weak side of the government on power to the developed world which reduces the country's representation at world stage.

\section{Overview of Initiatives of the Ethiopian Government to Attract and Use the Potential of Diaspora}

Though short of detailed description, EPRDF has its own strategies towards the Ethiopian Diaspora. Until the 2005 elections, EPRDF does not take the diaspora as enemy of the state. Even though there was a frosty relation between the Diaspora and the EPRDF, the government has taken actions to encourage them to return home and take part in the socioeconomic development endeavors that the country has embarked on. Because of lack of access to the official Ethiopian Diaspora policy, I am forced to use the following declarations and laws enacted by the EPRDF government.

\subsection{Proclamations No-270/2002- Provision of Identification Card for Foreign Nationals of Ethiopian Origin}

According to this proclamation, an individuals who even acquired other country's citizenship, his /her origin being Ethiopia, has a right to gain special Identification Card, which gives special privileges for foreign nationals of Ethiopian origin. The holder of the Identification Card is entitled to privileges and rights like entering the country without entry visa, to live without residence permit, the right to work in Ethiopia without a work permit and be considered as domestic investor and invest in areas allowed to Ethiopian investors without discrimination (Federal Negarit Gazeta, No. 270/2002:5). The service charge for the Identification card is 500 USD and 200 USD to renew on the bases of two years interval. This is criticized as expensive and not considering the long term gains from the Diaspora.

\subsection{Proclamation No. 378/2003, the New Citizen Ship Law}

The first citizenship law of Ethiopia, which was issued in 1930, existed for the last eight decades without amendment. The changing socio political conditions were not considered for about 80 years (Derara, 2003:23). The New Proclamation No.378/2003 seems a timely response to some important changes in the country. For instance, to be admitted as the Ethiopian citizen according to the 1930 citizenship law, the applicant was expected to speak and read Amharic. But, in the current proclamation that was changed. So long as the individual speaks and writes the language of any nation and nationality of Ethiopia, he/she can be considered Ethiopian (Federal Negarit Gazeta, No. 378/2003:4). But, the basic essence of the two proclamations does not change. Both do not allow dual citizenship and hence an immediate withdrawal is taken when acquiring another citizenship.

\subsection{Custom Regulation of the Ministry of Revenue for Returnees}

Since November, 2001, the Ministry of Revenue issued regulations aimed at giving duty and tax free entitlements for Ethiopians returning to their country permanently. Its basic rational is to ease and encourage the Diaspora to return to Ethiopia. The positive aspects of the regulation are its nondiscrimination with regard to means of migration out of the country, legally or illegally (Solomon, 2008). The regulation takes into consideration the fact of illegal migration specially fearing political persecution. But, in 2006, (one year after the controversial elections of 2005), the provision was lifted as the government suspected that vehicles were being singed over to third parties without paying duty which violated the law.

\subsection{Provision of Residential Houses for the Diaspora}

Residential house provision is a crucial question raised by almost all expatriates planning or intending to return. According to Proclamation No. 270/2002, the government of 
Ethiopia has granted the right to construct a house in any part of the country for the holders of the Identification Card and persons of Ethiopian origin. The first offer granted was $175 \mathrm{~m}^{2}$ of land free and beyond that with lease payments. However, the offer of $175 \mathrm{~m}^{2}$ of land is reduced to $50 \mathrm{~m}^{2}$ lands currently. In the first grant, it was possible for an individual to build villas but currently it is decided to be a condominium construction, that is, group buildings with shared walls and premises. Making land available for the Diaspora is a wise decision as it provides a possible returning of the Diaspora. But the irregularities seen in offer are not encouraging.

\subsection{Diaspora Bond}

This was initiated so as to raise investment capital for the Ethiopian Electric Power Corporation (EEPCo) and in away to accustom the diaspora of the opportunities they have. The minimum amount is 500 USD and the interest rates are $4 \%$, $4.5 \%$ and $5 \%$ for five, seven and ten year's maturity (MoFA, 2011). The bonds are tax free in Ethiopia and the interest is paid annually. The bond can also be used as collateral for borrowing from local banks in local currency. This is a rational policy to engage the Diaspora in the development activities. However, very few members of Ethiopian Diaspora become a part of this bond because of the uncompromising political out looks of the majority of the Diaspora.

\subsection{Institutions Responsible for Diaspora Engagement}

The existence or absence of institutions to address an issue shows the emphasis given to it. Institutional management with efficient and effective professionals is a crucial for successful achievement of goals. Any plan or objective to work with Diaspora definitely needs a body to take care of it (Joseph, 2004).

Ethiopia, however, does not have a specific ministry that is responsible for Diaspora engagement [as in the case of Ghana, Nigeria and India] that is charged with multiple objectives but has several departments [in different ministries] working on different aspects of Diaspora engagement (Kuschminder and Siegel, 2010:11). At the national level, the Ethiopian government has three different bodies dealing with Diaspora. The General Directorate for Ethiopian Expatriates (Ministry of Foreign Affairs), The Ethiopian Diaspora Coordinating Office (Ministry of Capacity Building) and the Diaspora Desk in the Addis Ababa City Government Investment Authority. At regional level, there are branches of Diaspora coordinating offices that also engaged directly with the Diaspora abroad. Finally, the Ethiopian Investment Agency and the Development Bank of Ethiopia are financial institutions under the Ethiopian National Bank that are involved in Diaspora engagement. This institutions, however, lacks competent man power for rendering effective delivery of services for their customers. One can easily observe bureaucratic difficulties and the prevalence of corruption as another challenge in these institutions.

\section{Factors Hindering the Engagement of Ethiopian Diasporas in the Development of the Country}

Even though Ethiopia is making a coordinated effort to attract its Diasporas to participate in the development effort of the country, there are multi-faceted problems which the Diasporas argue hinders their participation such as lack of conducive political and economic environment including implementation capacity, inefficient government bureaucracies, weak institutions and corruption (Seyoum, 2000). During the discussion with the Diasporas at Sheraton Addis on January 21, 2011 for the realization of the governments five years Growth and Transformation Plan (GTP), some of the participants stated that even though they are ready to participate for the success of the GTP, lack of justice and good governance at the grass roots (Kebele and Woreda) levels they have witnessed in the country so far, will be a major obstacles (www.newbusinessethiopia.com) accessed on June 6, 2011 at 5:30 pm. Without justice, good governance and competent civil servants at Kebele and Woreda level, whatever attractive plans the government designs, it does not work.

Between 2002 and 2006, the Ethiopian government had encouraged the Diasporas to engage in economic development by allowing easy movement of capital, goods and persons into the country and offering the expatriates economic incentives to return or invest in the country. However, in 2006 most of these special privileges were suspended. The suspension of these special privileges created disappointment among the Diasporas (Chacko and Marie, 2009:12).

In addition, some of the Diasporas (particularly Amhara elites) opposed and rejected the EPRDF's plan to structure Ethiopia on the basis of ethnically defined regions. They argued that EPRDF's plan to build Ethiopia on ethnically based regions (ethnic federalism) prepares the country for disintegration by creating ethnic cleansing among ethnic groups of the country (Lyons, 2009). As a result, the EPRDF government faced opposition from the leading members of the Amhara elites from the very beginning. On the other, the concern of Oromo Diaspora was/is not with the government's plan of structuring the country along ethnic lines; rather the nations and nationalities right to self determination enshrined in constitution should be practically put into effect. It is obvious that the issue of self-determination is highly contested issue in the current Ethiopian politics and the Oromo diaspora believe that the position of Oromo people in the Ethiopian state is not at par with its resource and contributions. Thus, the Oromo people is not benefitting from its resource rather the ruling class are exploiting it and therefore, Ethiopian federalism is not a federalism based on mutual benefit and equality, but in which one benefitted and others exploited. Thus, the hierarchical relationship between regions/ethnic groups/ should be solved first to be a development partners in the country (Human Rights Watch, 
2009).

Moreover, most of the Ethiopian Diasporas criticize the new Charities and Societies Proclamation of 2009 (Proclamation No.652/2009) and Anti-Terrorism Law arguing that EPRDF uses these laws to suppress or eliminate Ethiopian human rights NGOs and the opposition groups respectively. The charities and Societies Proclamation restricts organizations that receive more than $10 \%$ of funding from foreign sources from working in the areas of human and democratic rights, conflict resolution, promotion of children's and disabled rights, and promotion of gender and religious equality. According to Amnesty International (2012), the Anti-terrorism law could "restrict freedom of expression, peaceful assembly, and the right to fair trial, with serious implications in the run up to Ethiopia's 2010 election." Of course, as of most observers noted, the conditions of human rights in the country are deteriorating from time to time since that proclamation was declared. To this end, Human Rights Watch (2013) also warned that one of this law's more alarming features is how broadly and ambiguously terrorism is defined. The Diaspora sees these two laws as an "allergic" to the consolidation of immature Ethiopian democracy by weakening opposition parties and the civil societies working in the areas of human and democratic rights. The reason was that they already accustomed to the democratic values of the Western countries since lived there for a long period of time. Therefore, many of the Ethiopian Diasporas are not happy with human right conditions in the country during the last two decades and they argued that EPRDF government is formulating suppressive laws to systematically eliminate the opposition and opposition leaders.

The issue of freedom of press and the imprisonment and exile of journalists, bloggers are also some of the issues that the Ethiopian Diasporas repeatedly criticize. Because of these and other problems, Ethiopian Diasporas were not fully participating in the development effort of the country.

\section{Conclusion and Recommendation}

\section{A. Conclusions}

Diasporas can influence political processes and events in a significant ways. They also have a potential to influence economies and the process of wealth creation in home and host countries to much greater degree. In particular, Ethiopian Diasporas since they have lived for a long period of time in developed countries grasping modern education of science and technology; they are a powerful catalyst for innovation, economic growth and poverty reduction. They are the major sources of Foreign Direct Investment (FDI) and market development including out sourcing of production, technology transfer, philanthropy, tourism, political contributions and more intangible flows of knowledge, new attitudes and cultural influence.

The Ethiopian Diaspora, including its second and third generation, is among the country's critical intellectual resource whose maximum mobilization and engagement is indispensible. However, the majority of Ethiopian Diaspora is not engaging in the development efforts of the country as expected like Chinese and Indian diaspora, because of multifaceted problems of corruptions, bureaucratic bottlenecks, lack of good governance, and absence of participatory and inclusive political culture in the country's politics. Therefore, Ethiopian Diaspora has not been effectively mobilized, networked and engaged in the country's development endeavors.

B. Recommendations

The number and potential of the Ethiopian Diasporas are incredible. This potential is become useful to those countries where they reside. It is also valuable for the country to come back home. Considering their number and potential, the Ethiopian Diasporas can do much more. One can even say that they have ethical and moral responsibility to contribute to the socio-economic development of their country despite differences of political opinion.

Many countries Diasporas have done much better than the Ethiopian Diasporas. Important lessons from, Nigerian, Ghanian, Indians and Chinese Diaspora are important in this regard. Although, it may not be bad to be politicized if it is for a common cause, it is also much fruitful to think beyond politics and involved in development endeavors of the country.

The need for consensus building is the other necessary issues that the government and opposition leaders should feel responsible to address their political motives. Otherwise, opposition of destructive nature could hinder the development of the country. These create a sense of doubt on political system for the Diasporas living abroad. They may not be motivated to invest their knowledge, capital and skills in hostile political environment. On the parts of the Diasporas, there is a need to consider the general condition of the country and shape their expectations accordingly. Committed individuals can win in helping their country in any condition, not only on the steps taken by the government.

In the realm of political participation and membership, there are many ways to facilitate positive and productive diaspora engagement by incumbent government: In the first place, the questions of citizenship and the possibility of holding dual or multiple citizenship should be considered. In order to enhance the political participations of the Diaspora, the country may consider strengthening political ties to migrant populations, for instance, through out-of-country voting. This may perhaps strengthen their sense of belongingness to their country of Origin, Ethiopia.

Lastly, the government should also formulate a clear cut Diaspora policy and strategy which is comprehensive enough to accommodate all the Diasporas in order to enhance their participation in the development efforts of the country rather than temporarily flying to Europe and America for begging their dollar and knowledge on ad hoc basis. More than any other, this needs a commitment of the government on power, which is a sin quo non for the genuine return and involvement of the Diaspora in their country's development. 


\section{References}

[1] Abye Tasse (2004)," Ethiopians Routes in France, the united states". Paris, L. Harmattan.

[2] Alpers, Edward (2001), "Defining the African diaspora" paper presented to the center for Comparative Social Analysis Workshop, Los Angeles: University of California.

[3] Amnesty International (2012), "2012 Report on the state of the world's human rights", Peter Benenson House, UK, London.

[4] Bakewell, Oliver (2009), "Which Diaspora for whose Development? Some Critical Questions about the Roles of African Diaspora Organizations Development Actors," DIIS BRIEF.

[5] Bridgewater, Pamela (2003), "The African diaspora and its influence on African Development", remarks at Kentucky State University, Frankfurt, Kentucky.

[6] Butler, Kim (2001),” Defining Diaspora, Refining a Discourse", Diaspora 10

[7] Chacko, E and Price, Marie (2009) "The Role of the diasporas in Development: The case of Ethiopian and Bolivian immigrants in the USA" Department of Geography, George Washington University, Washington.

[8] Cheran, R. (2003), "Diaspora Circulation and Transnationalism as Agents for Change in the Post Conflict Zones of Sri Lanka" Department of Sociology and Centre for Refugee Studies, York University, Toronto, Canada.

[9] Derara Timotios (2003) "Dual nationality: comparative analysis with specific reference to the experience of Ethiopia" BA thesis, department of law, AAU, Addis Ababa.

[10] EIA (2011), Ethiopian Investment Agency Annual Report

[11] Easter and et al, 2010 at www. Ethiopiandiaspora.com accessed 27/08/2016.

[12] Ethiopian Nationality Law (1930), "Nationality of Children born of Ethiopian families in Ethiopia or abroad" Federal Negaret Gazeta, vol. 6 No. 3, Addis Ababa" Berhanena Selam printing press.

[13] Ethiopian Diasporas complain about good governance' at www.newbusinessethiopia.com accessed on June 6, 2016 at $5: 30 \mathrm{pm}$.

[14] Faist, Thomas (2010), 'Diaspora and transnationalism: What kind of dance partners?' in Rainer Bauböck and Thomas Faist (eds), Diaspora and Transnationalism: Concepts, Theories and Methods, Amsterdam: Amsterdam University Press.

[15] Federal Democratic Republic of Ethiopia (2002), "Provision of Identification Card for Foreign Nationals of Ethiopian origin" Federal Negarit Gazeta, No. 270

[16] Federal Democratic Republic of Ethiopia (2003) "Citizenship Law" Federal Negarit Gazeta, No. 378

[17] Getachew Metaferia and Maigenet Shiferaw (1991) The Ethiopian Revolution of 1974 and the Exodus of Ethiopia's Trained Human Resources. Lewiston, New York: Edwin Miller.
[18] Herbest, E. Lorraine (2004), The dialectics of (dis) trust: Oromo Diaspora net lands, $\mathrm{PhD}$ dissertation, New school university: USA.

[19] Human Rights Watch (2009), Human Rights in Ethiopia: Through the Eyes of the Oromo Diaspora

[20] Human Rights Watch (2013), "They Want a Confession" Torture and Ill-Treatment in Ethiopia's Maekelawi Police Station.

[21] IOM (2008), 'World Migration: Managing Labour Mobility in the Evolving Global Economy'

[22] Ionescu, Dina (2007), "Engaging Diaspora as development partners for home and Destination countries: challenges for policy makers". International Organization for Migration, Geneva.

[23] Joseph, Yalab (2004) "Reversing Ethiopian Brain Drain: National imperative," at www.ethiopiadiaspora.Com assessed on June, 6, 2015.

[24] Kassahun Berhanu and et al (2004), "Using resource from migrants for development in Ethiopia" paper presented at workshop on mobilizing and utilization of Diaspora as resource for development in Ethiopia, organized by IOM, Addis Ababa, Hilton, 2004.

[25] Kothari, C. R (2004). Research methodology: Methods and techniques. India: New Age International Publishers.

[26] Kuschminder, K. and Siegel, M. (2010), "Understanding Ethiopian Diaspora Engagement Policy," Maastricht Graduate School of Governance.

[27] Kuschminder, Katie (2010), "Diaspora Engagement in Ethiopia: Finding its Footings", Migration Policy Brief, No.4, Maastricht Graduate School of Governance.

[28] Lenin, V. I. (1972). Fundamental of Marxism -Leninism. Moscow: Progress Publishers.

[29] Levitt, P. and Jaworsky, N. (2007) "Transnational migration studies: past developments and future trends", Annual Review of Sociology 33: page 132 (129-156).

[30] Lyons, Terrence (2009), 'Ethiopian Diaspora and homeland conflict', in the proceedings of the $16^{\text {th }}$ International Conference of Ethiopian studies, ed. by Sven Edge, and et al.

[31] MoFA (2011), "Basic Information for Ethiopians in the Diasporas” Diaspora Engagement Affairs General Directorate.

[32] MoFA (2005), Newsletters, Ethiopian Expatriate Affairs Directorate General.

[33] Mohammed, Awol (2009), "The EU, the African diaspora in Europe and its impact on Democracy Building in Africa," African diaspora Policy Centre, Amsterdam.

[34] Newland, Kathleen (2004), "Beyond Remittances: The role of diasporas in poverty Reduction in their countries of origin" Scoping Study by the Migration policy Institute for the department of International Development, Washington DC.

[35] Orozco, Manuel (2006), "The Role of Diasporas in Developing the Homeland," Inter-American Dialogue, Paper presented at the, George Washington University, Washington, DC. 
[36] Pankhurst, Richard and et al. (2003), The African Diaspora in the Indian Ocean, Trenton, Africa World Press.

[37] Prah, Kwesi (2006), African Nation: The State of the nation, CASAS Book series, No.44 the Center for Advanced study of African society (CASAS), Cape Town.

[38] Proctor, James (2003), "Diaspora" in john McLeod (ed.) The Rout ledge companion to post colonial studies, Rout ledge: London.

[39] Robinson, Jenny (2002), Development and Displacement. Oxford: Oxford University Press.

[40] Rodney, Walter (1972). How Europe Underdeveloped Africa. London: Bogle-L'Overtures Publications.

[41] Rostow, W. W (1960), the Stages of Economic Growth: A Non- Communist Manifesto. Cambridge: Cambridge.

[42] Seyoum Tefera (2000), "the Cause and Magnitude of Brain Drain in Higher Education Institutions" with particular reference to AAU on Ethiopian development forum, vol. 1 No. 3 .
[43] Sheffer, Gabriel. (2006) Diaspora Politics: At Home Abroad. Cambridge: Cambridge University Press.

[44] Shinn, David (2002), "Reversing the Brain Drain in Ethiopia" in speech delivered on "North America Health Profession Association”. George Washington University, Elliot school of International Affairs: Alexandria.

[45] Solomon G/Amlak (2008)," Unity Advocated by Diaspora Intellectuals versus EPRDF's policy", The Hebrew university of Jerusalem.

[46] Todaro, M. \& Smith, S. (2014), Economic Development, New Jersey: Pearson, $12^{\text {th }}$ edition.

[47] Xing, Li and Opuku- mensah, P (2008), "Diaspora in Development and Integration: the Case of Chinese and African Diasporas", Center for Comparative Integration Studies. CCIS Research Series, Working paper No.7.

[48] Zeleza, Paul (2005), "Contemporary African Migration in a Global context: towards building the Black Atlantic, "essay for the $10^{\text {th }}$ CODESRIA General Assembly, Kampala. 